ISSN 2442-3041

Math Didactic: Jurnal Pendidikan Matematika

Vol. 1, No.1, Januari - April 2015

(C) STKIP PGRI Banjarmasin

\title{
IMPLEMENTASI PENDEKATAN SCIENTIFIC UNTUK MENINGKATKAN KEMANDIRIAN BELAJAR MATEMATIKA ${ }^{7}$
}

\author{
Syamsir Kamal \\ SMA Negeri 10 Banjarmasin \\ E-mail: kamalsyamsir@yahoo.co.id
}

\begin{abstract}
Abstrak: Kemandirian belajar siswa dalam matematika merupakan salah satu aspek yang ikut menunjang kesuksesan dan prestasi siswa dalam belajar matematika. Salah satu pendekatan pembelajaran yang bisa meningkatkan kemandirian belajar matematika siswa adalah pendekatan scientific. Tujuan penelitian ini untuk mendeskripsikan pembelajaran dengan pendekatan scientific yang dapat meningkatkan kemandirian belajar matematika siswa. Penelitian ini adalah penelitian dengan jenis penelitian tindakan kelas. Penelitian ini dilaksanakan di Kelas X SMA Negeri 10 Banjarmasin. Hasil penelitian menunjukkan bahwa pembelajaran dengan pendekatan scientific yang dapat meningkatkan kemandirian belajar matematika siswa terdiri dari 5 (lima) langkah atau yang disingkat dengan 5M, yaitu: (1) Mengamati, (2) Menanya, (3) Mengasosiasi, (4) Mengumpulkan informasi dan, (5) Mengomunikasikan mampu meningkatkan kemandirian belajar matematika siswa.
\end{abstract}

Kata kunci : pendekatan scientific, kemandirian belajar matematika siswa

Matematika adalah salah satu mata pelajaran yang diajarkan di SMA. Perolehan nilai matematika di SMA Negeri 10 Banjarmasin lebih rendah dibandingkan dengan nilai mata pelajaran lainnya. Hal ini menggambarkan bahwa kemampuan Matematika siswa SMA Negeri 10 Banjarmasin secara umum masih tergolong rendah. Salah satu indikator adalah seringnya kesalahan - kesalahan siswa dalam mengerjakan soal sehingga mengakibatkan rendahnya prestasi belajar siswa berupa nilai atau skor baik dalam ulangan harian, ulangan semester, maupun ujian akhir sekolah, padahal dalam pelaksanaan proses pembelajaran di kelas biasanya guru memberikan tugas (pemantapan) secara kontinu berupa latihan soal. Kondisi riil dalam pelaksanaannya latihan yang diberikan tidak sepenuhnya dapat meningkatkan kemampuan siswa.

Banyak faktor yang menjadi penyebab rendahnya hasil belajar Matematika siswa, salah satunya adalah ketidaktepatan penggunaan pendekatan pembelajaran yang digunakan guru di kelas. Kenyataan di lapangan menunjukkan bahwa selama ini guru masih mengajar menggunakan cara yang biasa (ceramah) dan banyak didominasi serta

\footnotetext{
${ }^{7}$ Disampaikan pada Seminar Nasional Pendidikan Matematika STKIP PGRI Banjarmasin, 28 Januari 2015
} 
masih berfokus pada guru. Pola pembelajaran seperti itu harus diubah dengan cara menggiring siswa mencari ilmunya sendiri. Guru hanya sebagai fasilitator, sedangkan siswa harus menemukan konsep-konsep secara mandiri. Untuk mengantisipasi masalah di atas, guru dituntut mencari dan menemukan suatu cara dan pendekatan pembelajaran yang dapat menumbuhkan kemandirian belajar peserta didik. Dalam pengajaran matematika diharapkan siswa mampu belajar mandiri, karena matematika adalah ilmu hitung yang harus dikaji secara lebih dalam agar mendapatkan hasil belajar yang memuaskan. Namun demikian kemandirian dan hasil belajar bukanlah satu keterkaitan yang harus ada. Kemandirian belajar sangat penting dimiliki oleh siswa, siswa yang mandiri belajar berarti siswa tersebut memiliki sifat dan perilaku, merasakan seseatu, bernalar dan mengambil keputusan sesuai dengan kemampuannya sendiri. Semangat kemandirian siswa yang tumbuh dari dalam diri siswa itu sendiri tidak menutup kemungkinan akan memunculkan hasil belajar yang baik. Apabila siswa sudah merasa nyaman dan menyenangkan secara pribadi, siswa terdorong untuk memperbaharui hasil belajarnya, dari perubahan pola kemandirian belajar tersebut.

$$
\text { Menurut Tandilling (2012:30) }
$$

kemandirian belajar siswa (self regulated learning) ikut menentukan keberhasilan belajar matematika. Tahar (2006:92) menyatakan bahwa kemandirian merupakan sikap yang memungkinkan seseorang melakukan sesuatu atas dorongan sendiri, kemampuan mengatur diri sendiri untuk menyelesaikan masalah dan dapat bertanggungjawab terhadap keputusan yang diambil. Pentingnya kemandirian belajar merupakan tuntutan kurikulum agar siswa mampu menghadapi persoalan baik di kelas maupun di luar kelas yang semakin kompleks dan tidak bergantung pada orang lain. Sedangkan menurut Qohar (2011:36), agar dapat mempunyai kemandirian dalam belajar siswa harus mempunyai pengetahuan tentang dirinya, tentang subyek yang akan dipelajari, tentang tugas, tentang strategi belajar dan tentang aplikasi dari subyek yang dipelajari. Kemandirian belajar yang baik mendapat hasil belajar yang baik karena dengan kemandirian siswa termotivasi aktif belajar atas dorongan dirinya sendiri. Dengan belajar aktif siswa akan berusaha memecahkan masalah yang diberikan guru.

Berkaitan dengan masalah tersebut, berdasarkan pengalaman peneliti selama mengajar di SMA Negeri 10 Banjarmasin bahwa ketika kegiatan pembelajaran matematika berlangsung ditemukan rendahnya kemandirian belajar matematika siswa yang mengakibatkan rendahnya hasil belajar siswa. Penyebabnya adalah antara lain kurangnya motivasi belajar siswa, rendahnya keaktifan siswa dalam pembelajaran, kurang semangat belajar dan kejenuhan dalam kelas. Penyebab-penyebab dari rendahnya kemandirian belajar pada siswa dapat muncul dari guru, siswa, lingkungan dan sarana prasarana. Pada suasana pembelajaran guru kadang menciptakan proses pembelajaran yang menjenuhkan dan kurang membangun siswa untung tertantang. Sehingga siswa menjadi jenuh dalam suasana kelas dan siswa sendiri juga tidak mampu belajar aktif, sikap siswa seharusnya mampu belajar mandiri. Berbagai usaha telah dilakukan guru dalam mengatasi masalah tersebut, seperti menerapkan diskusidiskusi dalam kelas namun usaha tersebut belum cukup berhasil dalam menangani masalah tersebut.

Usaha guru dalam membelajarkan peserta didik merupakan bagian yang sangat penting dalam mecapai keberhasilan tujuan pembelajaran yang sudah direncanakan. Oleh karena itu pemilihan berbagai model, metode, strategi, dan pendekatan serta teknik pembelajaran suatu hal yang utama. Salah satu pendekatan pembelajaran yang dikembangkan Sejalan diawalinya penerap- 
an kurikulum 2013 adalah pendekatan ilmiah, atau pendekatan saintifik, atau scientific approach yang menjadi bahan pembahasan yang menarik perhatian para pendidik.

Kemdikbud (2013:3) memberikan konsepsi bahwa penerapan pendekatan scientific didalam pembelajarannya mencakup komponen: mengamati, menanya, mencoba, mengolah, menyaji, menalar, dan mencipta. Tujuh aktivitas belajar tersebut merupakan aktivitas dalam mengembangkan keterampilan berpikir untuk mengembangkan ingin tahu siswa. Dengan itu diharapkan siswa termotivasi untuk mengamati fenomena yang terdapat di sekitarnya, mencatat atau mengidentifikasi fakta, lalu merumuskan masalah yang ingin diketahuinya dalam pernyataan menanya. Dari langkah ini diharapkan siswa mampu merumuskan masalah atau merumuskan hal yang ingin diketahuinya.

Selain ketepatan pendekatan pembelajaran, hal lain yang mungkin berpengaruh dan menentukan keberhasilan studi siswa adalah faktor intern seperti kemandirian belajar. Kebanyakan dari siswa belum mampu secara mandiri untuk menemukan, mengenal, memerinci hal-hal yang berlawanan dan menyusun pertanyaan-pertanyaan yang timbul dari masalahnya. Sebab siswa awalnya hanya menurut yang disajikan oleh guru atau masih bergantung pada guru. Keberhasilan belajar tidak boleh hanya mengandalkan kegiatan tatap muka dan tugas terstruktur yang diberikan oleh guru, akan tetapi terletak pada kemandirian belajar. Untuk menyerap dan menghayati pelajaran jelas telah diperlukan sikap dan kesediaan untuk mandiri, sehingga sikap kemandirian belajar menjadi faktor penentu apakah siswa mampu menghadapi tantangan atau tidak (Fitriana, 2010:24).

Peneliti yakin dengan pendekatan pembelajaran Scientific siswa akan lebih tertantang lagi untuk dapat menyelesaikan suatu permasalahan matematika yang ada. Akibatnya siswa termotivasi untuk lebih giat lagi mengikuti pembelajaran dan akhirnya akan menumbuhan kemandirian belajar siswa yang pada akhirnya prestasi belajar siswa akan lebih meningkat. Karena kemandirian belajar matematika merupakan faktor yang sangat penting dalam keberhasilan siswa dalam belajar matematika.

\section{Metode}

Penelitian yang dilakukan ini merupakan penelitian tindakan kelas. Peneliti menelaah proses dan hasil tindakan pembelajaran yang dilakukan secara sistematis dan terencana. Peneliti juga terlibat langsung dalam penelitian ini. Peneliti bertindak sebagai instrumen utama, karena peneliti sendiri yang merencanakan, merancang, melaksanakan, mengumpulkan data, dan menganalisis data, menyimpulkan serta melaporkan hasilnya.

Penelitian ini dilakukan dalam dua siklus. Setiap siklus terdiri dari perencanaan, pelaksanaan, observasi, dan refleksi. Data dikumpulkan dengan menggunakan teknik (1) observasi, (2) angket, dan (3) wawancara. Observasi untuk mengamati kegiatan pembelajaran dan mengamati kemandirian belajar siswa. Angket dan wawancara untuk mengetahui respon siswa terhadap kegiatan pembelajaran dengan pendekatan scientific dan penigkatan kemandirian belajar matematika siswa.

Subjek pada penelitian ini adalah siswa kelas X.3 SMA Negeri 10 Banjarmasin tahun pelajaran 2013/2014 yang berjumlah 32 siswa,. Kriteria keberhasilan tindakan adalah 80\%. Selain itu kemandirian belajar siswa dianggap meningkat jika kriteria minimal 75\%. Penelitian dilaksanakan pada semester genap bulan April 2014.

Kegiatan-kegiatan dalam siklus dan tahap yang dilakukan sebagai berikut: 


\section{Perencanaan}

Kegiatan yang dilaksanakan pada tahap perencanaan adalah menyusun rancangan yang akan dilaksanakan, yang terdiri dari :

1. Mempersiapkan perangkat pembelajaran yaitu rencana pelaksanaan pembelajaran (RPP) dan lembar kerja siswa (LKS).

2. Mempersiapkan instrumen untuk mengumpulkan data, berupa lembar observasi aktivitas siswa dan guru, lembar observasi kemandirian belajar siswa, angket kemandirian belajar siswa, pedoman wawancara, lembar tes, dan lembar validasi beserta proses validasi yang telah di validasi oleh validator.

\section{Pelaksanaan}

Pada tahap pelaksanaan guru melaksanakan pembelajaran dengan menerapkan pendekatan scientific. Guru menerapkan RPP, selama pelaksanaan diobservasi oleh dua orang guru matematika baik aktivitas siswa maupun aktivitas guru, merefleksi kegiatan pada akhir siklus. Jika sesuai dengan kriteria keberhasilan maka siklus akan berhenti namun jika belum sesuai maka dilanjutkan ke siklus selanjutnya.

Teknik analisa data yang digunakan adalah: (1) data hasil validasi perangkat pembelajaran dan instrumen penelitian, (2) data hasil observasi aktifitas guru dan siswa, (3) data hasil observasi kemandirian belajar siwa, (4) data hasil angket kemandirian belajar, dan (5) data hasil tes.

\section{Hasil dan Pembahasan}

Sebelum pelaksanaan tindakan dilakukan peneliti sudah mempersiapkan perangkat pembelajaran dan instrumen penelitian yang sudah di validasi oleh validator, hasil validasi dari dua orang validator menunjukkan bahwa perangkat pembelajaran dan instrumen penelitian berada pada kategori valid.

Tahapan pelaksanaan tindakan sesuai dengan tahapan langkah-langkah belajar dengan menggunakan pendekatan scientific yang meliputi : mengamati, menanya , mengumpulkan informasi, mengasosiasi, dan mengomunikasikan. Untuk lebih lengkapnya langkah-langkah pendekatan scientific dan tindakannnya dapat dilihat pada Tabel 1 di bawah ini.

Tabel 1 Langkah-langkah pendekatan scientific dalam pembelajaran matematika

\begin{tabular}{|l|l|l|}
\hline No & \multicolumn{1}{|c|}{ Langkah-langkah } & \multicolumn{1}{c|}{ Tindakan } \\
\hline 1. & mengamati & $\begin{array}{l}\text { - Guru mengajukan pertanyaan pengarah untuk } \\
\text { mengetahui sejauh mana tanggapan siswa terhadap } \\
\text { pengamatan yang mereka lakukan pada permasalahan } \\
\text { (gambar) yang disajikan } \\
\text { - Siswa menjawab pertanyaan guru dan siswa lain juga } \\
\text { mengomentari jawaban dari temannya }\end{array}$ \\
\hline 2. & menanya & $\begin{array}{l}\text { - Siswa diminta membuat pertanyaan mengenai } \\
\text { permasalahan yang diberikan oleh guru }\end{array}$ \\
\hline 3. & menggali/mengumpulkan & $\begin{array}{l}\text { - Siswa mengumpulkan informasi dan mengolah informasi } \\
\text { yang sudah di dapat dari pengetahuan sebelumnya serta } \\
\text { mencari solusi permasalahan dari berbagai sumber }\end{array}$ \\
\hline 4. & mengasosiasi & $\begin{array}{l}\text { - Siswa mengaitkan fakta yang satu dengan fakta yang lain } \\
\text { dari hasil penggalian informasi. } \\
\text { - Siswa memberikan alasan logis terhadap proses yang } \\
\text { didapatkanya }\end{array}$ \\
\hline 5. & mengomunikasikan & $\begin{array}{l}\text { - Siswa menyampaikan kesimpulan akhir hasil diskusinya } \\
\text { baik secara tertulis maupun lisan. }\end{array}$ \\
\hline
\end{tabular}


Persentase skor rata-rata hasil observasi guru, hasil observasi siswa, dan observasi kemandirian belajar siswa pada siklus I dan siklus II ditunjukkan pada Tabel 2 , sedangkan hasil analisis angket kemandirian belajar matematika siswa ditunjukkan pada Tabel 3 berikut ini dan perhitungan angket kemandirian belajar matematika siswa adalah $75,71 \%$ sudah memenuhi kriteria skor minimal yaitu $75 \%$. Karena semua kriteria sudah terpenuhi maka penelitian tindakan kelas ini dinyatakan berhasil dan tidak dilanjutkan ke siklus selanjutnya.

Tabel 2 Persentase skor rata-rata hasil observasi guru, observasi siswa, dan observasi kemandirian belaiar siswa

\begin{tabular}{|c|c|c|c|}
\hline Hasil Penelitian & \multirow{2}{*}{$\begin{array}{c}\text { Observasi } \\
\text { Guru }\end{array}$} & $\begin{array}{c}\text { Observasi } \\
\text { Siswa }\end{array}$ & $\begin{array}{c}\text { Observasi Kemandirian } \\
\text { Belajar Siswa }\end{array}$ \\
\cline { 1 - 2 } Siklus & $83,04 \%$ & $78,85 \%$ & $61,46 \%$ \\
\hline I & $91,97 \%$ & $86,54 \%$ & $79,17 \%$ \\
\hline
\end{tabular}

Tabel 3 Persentase hasil angket kemandirian belajar matematika siswa per indikator

\begin{tabular}{|c|c|c|c|c|c|}
\hline $\begin{array}{r}\text { Indikator } \\
\text { Kemandirian }\end{array}$ & Percaya diri & Inisiatif & $\begin{array}{c}\text { Tanggung } \\
\text { jawab }\end{array}$ & Motivasi & Rata-rata \\
\cline { 1 - 5 } Siklus & & & & & $63,65 \%$ \\
\hline I & $69,53 \%$ & $65,36 \%$ & $63,91 \%$ & $55,78 \%$ & $75,71 \%$ \\
\hline
\end{tabular}

Dari tabel tampak bahwa hasil observasi aktivitas guru pada siklus I sudah tercapai yaitu $83,04 \%$ sudah memenuhi kriteria baik yaitu minimal mencapai $80 \%$ sedangkan hasil observasi aktivitas siswa sebesar $78,85 \%$ belum memenuhi kriteria. Hasil observasi kemandirian belajar siswa pada siklus I ini adalah $61,25 \%$ juga belum memenuhi kriteria minimal observasi kemandirian yaitu $75 \%$. Hasil perhitungan angket kemandirian belajar matematika siswa adalah $63,65 \%$ juga belum memenuhi kritria skor minimal yaitu $75 \%$. Karena ada kriteria yang belum tercapai maka pembelajaran dilanjutkan ke siklus II dengan memperbaiki kelemahan yang ada pada siklus I.

Hasil observasi aktivitas guru pada siklus II sudah tercapai yaitu $91,97 \%$ sedangkan hasil observasi aktivitas siswa sebesar $86,54 \%$ keduanya memenuhi kriteria sudah memenuhi kriteria baik yaitu minimal mencapai $80 \%$. Hasil observasi kemandirian belajar siswa pada siklus II adalah 79,17\%
Berdasarkan hasil refleksi siklus I terhadap hasil pengamatan, pada pertemuan awal siswa belum terbiasa dengan pembelajaran dengan pendekatan scientific karena karekteristik dari pendekatan ini adalah pembelajaran yang berpusat pada siswa (student centered). Peneliti tidak memberikan penjelasan materi dan contohcontoh penyelesaian soal. Namun siswa langsung mempelajari permasalahan yang ada pada LKS baik pada tahap mengamati, megumpulkan informasi maupun mengasosiasi. Piaget menyatakan bahwa "learners of any age are actively involved in the process of acquiring information and constructing their own knowledge" (Arends, 2012:400). Hal ini berarti siswa yang harus aktif dalam membangun pengetahuannya dan peneliti sebagai fasilitator. Keadaan tersebut sangat berbeda dengan pengalaman yang di alami oleh siswa selama ini dalam belajar matematika. Pada pembelajaran sebelumnya siswa terbiasa mendengarkan guru ceramah 
menyampaikan materi, kemudian diberi contoh soal dan mengerjakan soal yang serupa dengan contoh soal yang sudah diberikan.

Implementasi pendekatan scientific yang salah satu karakteristiknya adalah pembelajaran yang berpusat pada siswa (student centered) ternyata berdampak pada siswa. beberapa siswa selalu menanyakan apakah hasil pekerjaan mereka benar atau tidak. Siswa ragu-ragu dalam menuliskan jawabannya. Oleh karena itu, peneliti akan melakukan pemberian arahan atau bimbingan dalam bentuk scaffolding kepada siswa yang memerlukannya. Hal ini karena tingkat kemampuan siswa dalam memahami permasalahan juga berbeda-beda, sehingga peneliti tidak bisa memberikan arahan dan bimbingan secara klasikal, ketika siswa mengerjakan tugas, guru tidak boleh duduk diam dan membiarkan siswa mengerjakan sendiri sesuai dengan kemampuannya. Kalau itu terjadi, maka menurut Chaiklin (dalam As'ari,2014:12) terkait dengan teori ZPD (Zone of proximal development) "siswa hanya akan sampai kepada tingkat kemampuan aktualnya. Tapi, kalau guru mendampingi mereka, dan memberikan bantuan (scaffolding) yang sesuai dengan yang diperlukan, mereka berpeluang untuk sampai kepada kemampuan idealnya".

Siswa juga kurang aktif dalam bertanya dan menyampaikan pendapat serta mengomunikasikan hasil temuan atau pekerjaannya sehingga kegiatan belajar menjadi kurang semangat dan belum menumbuhkan kemandirian belajar matematika siswa. salah satu faktornya adalah siswa masih malu, kurang percaya diri, belum ada inisiatif, dan takut untuk bertanya dan mengeumukakan pendapat. Guru kurang berusaha untuk mengaktifkan siswa sehingga suasana pembelajaran menjadi kurang lancar dan efektif. Oleh karena itu peneliti akan memberikan perhatian dan motivasi yang lebih kepada siswa agar siswa mau bertanya, menjawab pertanyaan guru, mengemukakan dan mengomunikasikan pendapat serta menanggapi dan bertanya kepada teman yang sedang presentasi. Hal ini sesuai pendapat Nurhalisah (2010:206) yang menyatakan bahwa "untuk mengaktifkan siswa yang diam guru hendaknya memberikan perhatian dengan memberi kesempatan bertanya, mengamati dan menganalisis materi".

Pada siklus II ini siswa sudah terbiasa dengan pembelajaran dengan menggunakan pendekatan scientific. Siswa sebagian besar sudah dapat memahami apa yang harus mereka lakukan pada tahap-tahap pembelajaran dengan pendekatan scientific hanya beberapa siswa yang masih belum terbiasa khususnya pada tahap menanya, mengasosiasi dan mengomunikasikan. Akan tetapi hal itu tidak mengganggu jalannya proses pembelajaran dan secara umum proses belajar mengajar berlangsung baik dan lancar. Siswa sudah berani bertanya dan menjawab pertanyaan serta mengemukakan pendapat sampai akhirnya mengomunikasikannya dengan siswa lain. Hal ini disebabkan karena adanya pemberian motivasi yang lebih dari guru terhadap siswa. Guru melakukan pendekatan kepada siswa yang kurang percaya diri, belum berani berinisiatif sendiri, memberitahukan kepada siswa bahwa siswa tidak boleh malu untuk bertanya. Peneliti yang berperan sebagai guru berusaha untuk menjadi teman siswa, sehingga siswa tidak ada yang malu lagi untuk bertanya. Hal ini senada dengan pendapat Nurani (2013:40) yang menyatakan bahwa "pembelajaran yang efektif ditandai dengan adanya upaya untuk melibatkan siswa secara aktif dan membangun komunikasi yang konstruktif antara guru dengan siswa maupun siswa dengan siswa". Selain itu pemberian bantuan dalam bentuk scaffolding juga sangat membantu siswa memahami permasalahan yang diberikan sehingga mereka terbiasa dalam menuliskan ide-ide matematis terkait materi pelajaran yang diberikan. 
Bantuan yang diberikan peneliti juga disesuaikan dengan tingkat kemampuan siswa. Daniels (dalam Santrock, 2011:191) menyatakan bahwa "Scaffolding means changing the level of support. Over the course of a teaching session, a more-skilled person (a teacher or advanced peer) adjust the amount of guidance to fit the child's current performance". Hal ini maksudnya bahwa sistem dukungan (scaffolding) sebagai teknik perubahan dukungan selama rangkaian pembelajaran dalam satu sesi pengajaran, seseorang yang lebih terampil (guru atau teman sebaya yang lebih pintar) menyesuaikan jumlah bimbingan agar sesuai dengan prestasi siswa pada saat ini. Guru sudah mampu berperan sebagai fasilitator dan membantu siswa selama proses pembelajaran berlangsung, ketegasan guru dalam mengingatkan siswa yang kurang serius dalam mengikuti pembelajaran sudah terlihat dengan beberapa kali menegur siswa yang kurang serius. Diskusi kelompok sudah berjalan dengan baik, karena dalam kelompok hanya beberapa siswa yang diam dan tidak mau bekerja sehingga terlihat ada keributan kecil dalam kelompok. Hanya 1-2 orang siswa yang suka mengobrol dan bercanda. memberikan pengawasan terhadap seluruh kelompok juga mempengaruhi siswa. Hal ini sesuai dengan pendapat Darmadi (2012:51) bahwa "guru wajib memberikan bimbingan dan penyuluhan kepada peserta didik pada waktu mereka menghadapi kesulitan dengan cara yang sesuai dengan kemampuan peserta didik dan kemauan yang ingin dicapai”.

Penyampaian tujuan pembelajaran dapat memberikan motivasi belajar pada siswa dan menjadikan siswa terfokus pada satu tujuan yang perlu mereka capai. Dalam penelitian ini, siswa nampak sangat antusias menyimak penyampaian tujuan pembelajaran oleh guru. Buktinya siswa benar-benar memperhatikan penyampaian tujuan. Keantusiasan siswa ini menjadi satu bukti bahwa siswa mulai termotivasi. Hal ini mendukung pendapat Dahar (1988:174) bahwa penyampaian tujuan pembelajaran selain dapat memotivasi juga dapat memusatkan perhatian siswa terhadap aspek yang relevan dalam pembelajaran.

Untuk lebih meningkatkan motivasi siswa, peneliti juga menyampaikan pentingnya materi dan aplikasinya dalam kehidupan sehari-hari, misalnya untuk dalam bidang navigasi dan untuk menghitung tinggi bangunan,pohon bahkan pegunungan bahkan juga menghitung jarak antara benda-benda diangkasa. Oleh para arsitek trigonomeri diaplikasikan untuk menghitung beban struktural, kemiringan atap bahkan permukaaan. Ternyata siswa juga tertarik dengan penyampaian pentingnya materi trigonometri. Hal ini didukung pendapat Orton (2006:11) bahwa siswa yang termotivasi, tertarik, dan mempunyai keinginan untuk belajar akan belajar lebih banyak.

\section{Kesimpulan}

Berdasarkan data hasil penelitian terhadap implementasi pendekatan scientific di kelas X.3 SMA Negeri 10 Banjarmasin, diperoleh kesimpulan bahwa Langkahlangkah pembelajaran dengan pendekatan scientific yang dapat meningkatkan kemandirian belajar matematika siswa adalah sebagai berikut :

1. Mengamati, pada kegiatan ini setelah siswa mengamati gambar dan permasalahan kontekstual seperti hubungan antara kawat/kabel penyangga yang dikaitkan pada pemancar radio dan dikaitkan ke tanah, selanjutnya guru mengajukan pertanyaan pengarah untuk mengetahui sejauh mana tanggapan siswa terhadap pengamatan yang mereka lakukan pada permasalahan (gambar) yang disajikan tersebut dan siswa menjawab pertanyaan guru dan siswa lain 
juga mengomentari jawaban dari temannya.

2. Menanya, pada kegiatan ini siswa diminta membuat pertanyaan mengenai permasalahan yang diberikan oleh guru. Pada awal kegiatan siswa yang bertanya masih diperintah oleh guru, siswa masih ragu-ragu dan malu-malu serta belum punya inisiatif yang tinggi juga kepercayaan diri untuk bertanya kepada guru, pada pertemuan selanjutnya siswa sudah berani bertanya tanpa di tunjuk oleh guru. Akan tetapi siswa masih belum bisa mengajukan pertanyaan yang bersifat investigatif (pertanyaan yang mendorong orang yang ditanya untuk melakukan eksplorasi terlebih dahulu sebelum menjawabnya). Hal ini terjadi karena siswa belum terbiasa dan pengkondisian yang selama ini terjadi dalam pembelajaran yang dialami siswa dimana guru yang selalu aktif sedangkan siswanya hanya pasif mendengarkan penjelasan guru.

3. Menggali/mengumpulkan informasi, pada kegiatan ini siswa siswa mengumpulkan informasi dan mengolah informasi yang sudah di dapat dari pengetahuan sebelumnya serta mencari solusi permasalahan dari berbagai sumber. Penggalian informasi yang siswa dapat cuma berbekal buku paket tidak menggunakan teknologi informasi seperti internet atau buku-buku matematika yang lain, hal ini terjadi karena minimnya fasilitas yang dimiliki oleh sekolah.

4. Mengasosiasi, pada kegiatan ini siswa mengaitkan fakta yang satu dengan fakta yang lain dari hasil penggalian informasi yang telah dilakukan dan memberikan alasan logis terhadap proses yang didapatkanya. Akan tetapi dalam kenyataannya siswa masih kesulitan untuk mengaitkan informasi dan pengetahuan yang mereka dapat sebelumnya.
5. Mengomunikasikan, pada kegiatan ini siswa menyampaikan kesimpulan akhir hasil diskusinya baik secara tertulis maupun lisan. Pada saat tahap mengomunikasikan ini hasil diskusi yang telah disampaikan oleh siswa di presentasikan di depan kelas akan tetapi apa yang disimpulkan itu belum mendapat komentar, tanggapan, kritik atau saran dari siswa lain. Jadi sifatnya hanya penyampaian hasil diskusi saja.

Setelah pengimplementasian pembelajaran melalui pendekatan scientific dalam pembelajaran matematika pada materi trigonometri di kelas X.3 SMA Negeri 10 Banjarmasin, kemandirian belajar matematika siswa kelas X.3 sudah mulai meningkat, hal ini terlihat dari hasil observasi dari peneliti dan observer dengan menilai aktivitas siswa, hasil wawancara dan diperkuat dengan diberikannya angket kepada siswa dengan berpedoman kepada indikator-indikator kemandirian belajar siswa yaitu percaya diri, inisiatif, tanggung jawab dan motivasi belajar, hasilnya siswa mampu menunjukkan aktivitas-aktivitas dalam pembelajaran matematika yang menunjukkan adanya peningkatan kemandirian belajar dalam diri siswa, setelah di implementasikannya pendekatan scientific dalam pembelajaran matematika di kelas X.3 SMA Negeri 10 Banjarmasin.

\section{Daftar Pustaka}

Arends, R.I. 2012. Learning To Teach $9^{\text {th }}$ Edition. New York: Routledge.

Arikunto. S., Suhardjono \& Supardi. 2010. Penelitian Tindakan Kelas. Jakarta: Sinar Grafika Offset.

As'ari, A.R. 2014. Pendekatan Saintifik Dalam Pelajaran Matematika. Makalah disajikan dalam Seminar Jurusan Matematika FMIPA Universitas Negeri Malang. 5 Maret 2014. 
Darmadi, H. 2012. Kemampuan Dasar Mengajar. Bandung : Alfabeta

Fitriana, L. 2010. Pengaruh Model Pembelajaran Cooperative Tipe Group Investigation (GI) Dan STAD Terhadap Prestasi Belajar Matematika Ditinjau Dari Kemandirian Belajar Siswa. Tesis (tidak diterbitkan). Surakarta: Universitas Sebelas Maret

Kemendikbud. 2013. Implementasi Kurikulum 2013, Materi Pelatihan Guru SMA-Matematika. Jakarta: Kementrian Pendidikan dan Kebudayaan, Pusat Kurikulum

Kemendikbud. 2013 Pendekatan Scientific (Ilmiah) dalam Pembelajaran. Jakarta: Departemen Pendidikan dan Kebudayaan, Pusbangprodik

Nurani, B. 2013. Efektifitas Pembelajaran Kooperatif Model STAD Terhadap Prestasi Belajar Fisika Ditinjau dari Motivasi Berprestasi Siswa SMA. Jurnal Pendidikan Sains, Volume 1, Nomor 1. Hal.35-47

Nurhalisah. 2010. Peranan guru dalam mengelola kelas. Jurnal Lentera Pendidikan Volume 13, Nomor 2. Desember 2010.

Permendikbud RI No. 65 Tahun 2013 tentang Standar Proses Pendidikan Dasar dan Menengah. Kementerian Pendidikan dan Kebudayaan Republik Indonesia.

Qohar, A. 2011. Asosiasi Antara Koneksi Matematis Dan Komunikasi Matematis Serta Kemandirian Belajar Matematika Siswa SMP. Makalah disajikan dalam Lomba dan Seminar Matematika (LSM) ke XIX di Universitas Negeri Yogyakarta. (Online) http://eprints.uny. ac.id/6967/1/Makalah\%20Peserta\%203 \%20\%20Abd.\%20Qohar1.pdf. diakses 23 September 2013

Santrock, J.W. 2011. Educational Psychology $5^{\text {th }}$ Edition. New York: McGraw-Hill.

Tahar, I. \& Enceng. 2006. Hubungan Kemandirian Belajar dan Hasil Belajar Pada Pendidikan Jarak Jauh. Jurnal
Pendidikan Terbuka dan Jarak Jauh, Volume. 7, Nomor 2.

Tandilling, E. 2012. Pengembangan Instrumen Untuk Mengukur Kemampuan

Komunikasi Matematik, Pemahaman Matematik, Dan Selfregulated Learning Siswa Dalam Pembelajaran Matematika Di Sekolah Menengah Atas. Jurnal Penelitian Pendidikan Vol. 13 No. 1, April 2012. 